\title{
Content Analysis of An Early Reading Textbook at Islamic Elementary School
}

\author{
${ }^{1}$ Fitri Puji Rahmawati, ${ }^{2}$ Sarwiji Suwandi, ${ }^{3}$ Andayani, ${ }^{4}$ Markhamah \\ ${ }^{1}$ fitripr2016@student.uns.ac.id, ${ }^{2}$ sarwijiswan@yahoo.com, ${ }^{3}$ andayani@yahoo.com, \\ ${ }^{4}$ markhamah@ums.ac.id \\ ${ }^{1,2}$ Universitas Sebelas Maret, Surakarta, Indonesia \\ ${ }^{3,4}$ Universitas Muhammadiyah Surakarta
}

\begin{abstract}
This article will describe the analysis of textbooks used by teachers to early reading learning for elementary school students in grade 1 . The data is obtained from interviews and observations in 3 Islamic elementary schools in Surakarta City, Indonesia. The teacher was teaching a beginning reading with Anak Islam Suka Membaca. On this ground, the book content was analyzed by content analysis methods. Book analysis is seen based on content, vocabulary, and grammar, exercises and activities, the attractiveness of the text and physical make-up. Findings indicate that the new vocabulary words presented in a variety of ways but some words are not meant so students are unable to know their meaning, students taught topdown techniques for learning new vocabulary words, the textbook has more activities book and nothing exercises, the cover of the book is not appealing, the visual imagery is not required aesthetic quality. The conclusion of the textbook is not enough making students enjoy reading.
\end{abstract}

Keywords: an early reading, elementary school, textbook

\section{Introduction}

\subsection{The Structure}

Textbooks are one of the most important aspects of learning. Yuliyanti[1] states that a textbook is a material of instruction which is organized properly. An early reading textbook has an important role in Indonesian Language subject matter for teachers and learners. According to Harmer[2], the main function of a textbook is to involve students with the particular material. Generally speaking, an early reading textbook is helps both teachers and early reader in reading learning.

In Surakarta, Indonesia, there are various of early reading textbooks used in islamic elementary school. One of the early reading textbook used is "Anak Islam Suka Membaca" (AISM). AISM is an early reading textbook published by

Pustaka Amanah Press. AISM is used by first grade students of SD Muhammadiyah 16 Surakarta, SD Muhammadiyah 19 Surakarta, and SD Muhammadiyah 18 Surakarta. As a textbook which is used in the classroom, AISM should be analyzed. The analysis would help the teacher to understand the feasibility of AISM for student.

Textbook evaluation is a process of choosing what textbook to use in a particular course considering the need and value of teaching. The purpose of textbook evaluation is to support the teacher development and help teachers in order to gain good and useful insights into the nature of material[3]. In short, the goal of textbook analysis is to decide on 'best of the best' material functioning as framework and resource of early reading teaching. 
This study was expected to give contribution for the following study and may contribute ideas to people involved in the education field. This study was intended to help the elementary school teachers to be more selective in choosing textbooks for students and in selecting the materials in order to expose the students to the best of the best materials that meet the teaching's value, teacher's syllabus, and other aspects. Additionally, this study could help future researchers as a useful reference. This study was also expected to help future materials writers to develop better materials.

The primary problem of this textbook content analysis was whether the content of AISM met the requirements of good textbook criteria cover four factors of consideration namely availability of materials, methodology, language skill, design and layout, organization, and language appropriacy.

\subsubsection{Reference citations}

There are many criteria proposed by several experts that can be used for evaluating textbooks. Those criteria are introduced by many experts of EFL textbook evaluation, for instance, Cunningsworth[3], Sheldon and Harmer[2]. Each expert has their own belief about the criteria of a good textbook. The crucial aspects in evaluating textbook are quite distinct among them. However, those particular differences are not problematic cases to be debated because over the years the relative importance of different textbook criteria would change, along with the interpretation given to the scores assigned in each category.

According to Cunningsworth[3], it is best for a textbook evaluator to identify her or his own priorities and draw up her or his own checklist by using some criteria mentioned in one book and adding others based on personal priorities. Concerning the statement of Cunningsworth, the author prefers to adapt the EFL textbook criteria and checklist from some experts, that is, Sheldon and Harmer[2]. Thus, the adaptation of good EFL textbook criteria taken from Sheldon, and Harmer[2] bring about the formulation of criteria of good EFL textbooks that consider several factors, namely: (1) the availability of materials, (2) language skills, (3) design and layout, (4) organization, (5) language appropriateness. These four factors of consideration are used by the author to analyse AISM.

\section{Related Works/Literature Review}

Tomlinson[4] states that textbooks are material designs that are a core part of learning. This book is usually related to the development of reading, listening, and speaking rather than just learning language. Textbooks become a very powerful set of tools in the learning process. This concludes that textbooks are an important component in learning that must be systematically arranged because textbooks can contribute to the development of the ability to read, write, or speak and other language learning.

Cunningsworth[3] states that textbooks are an effective source for direct self-learning, an effective source for presenting content by teachers, a source of ideas and activities, a reference source for students, a syllabus that reflects objective learning and helps less experienced teachers who are still not confident.

Textbooks are books that contain descriptions of materials about learning material or specific fields, arranged systematically and selected based on the goals, development of students, and learning orientation to be assimilated. The development of students today is in line with the development of technology that continues to advance. This also affects the form of textbooks. Textbooks have experienced development, Wibowo[5] states that textbooks have always been identified with lectures, modules, monographs and reference books. Many people still have difficulty distinguishing between textbooks and general books (trade book). Today, 
the development of textbook forms varies greatly because they are not only printed but also in the form of e-books, PDF books, online tutoring systems, and video lecture materials.

Tarigan[6] reveal several characteristics of textbooks, namely: (1) textbooks intended for students at certain levels of education; (2) always related to certain fields of study; (3) always a standard book; (4) usually compiled and written by experts (experts, experts) in their respective fields; (5) written for certain instructional purposes; (6) equipped with teaching facilities; (7) written for certain levels of education; (8) written to support a teaching program. This is in contrast to textbooks whose technical writing is not elaborated in detail because textbooks are arranged in a structure and sequence based on a particular field of science or based on academic interests.

The criteria for textbooks as well as non-contextual lessons that are suitable for use include fulfilling the skin elements of the book, the beginning, the content section, and the final part. Book skins on books must meet the front skin, back skin and back of the book. The initial section contains the title page, publishing page, page and can add an introductory page, table of contents, list of images, tables, and page numbering. The content section must fulfill linguistic, material, and graphic aspects. The final page fulfills information about the perpetrators of books and indexes, and can add a glossary, bibliography, and attachments (Government Regulation No. 8 of 2016).

The ideal textbook according to Andayani[7][8] is a book that can integrate various disciplines and learning strategies. Integrated approach is a learning approach that involves several fields of science. The involvement of various fields of science is done so that students get meaningful experience in each discipline.

Illustrations or pictures that are able to provide real or concrete illustrations are useful to make it easier to understand the substance and provide its own attraction. The indicators used in this study are indicators of the Indonesian Language Textbook Assessment Standards, namely: material, presentation, language and legibility, and graphics. These four aspects are interrelated with each other (Center for Curriculum and Books). An early reading is a reading teaching that is intended to provide students with the ability to convert a series of letters into meaningful sound sequences and smooth reading techniques[9].

\section{Material \& Methodology}

Dealing with analysis of textbook, this study was categorized as documentary analysis research. Since this study was categorized as documentary analysis, this study was on umbrella of qualitative research design. This study was also classified as Descriptive Qualitative Research Design. According to Bogdan and Biklen[10], descriptive is the characteristic of data in qualitative research because it was taken from documents, audio-video recordings, transcripts, words, pictures, etc.

Moreover, this study is categorized as qualitative research design because this study is aimed to check the quality of the textbook and find out its strengths and weaknesses toward the criteria of good textbook. Anderson[11] defined a descriptive presentation of qualitative data as content analysis. Content analysis is also a method used in analysing qualitative data. Content analysis is applicable to various studies including language studies, which concern with analysing content of certain matter through classification, tabulation, and evaluation. Based on the above-mentioned theory and elaboration, it can be concluded that the research design of analysis on AISM is categorized as descriptive qualitative content analysis. 


\subsection{Data}

The main source of data in this study is the content of textbook entitled Anak Islam Suka Membaca (AISM) is used by the first graders of elementary school at Islamc elementary school Surakarta. This textbook is the $16^{\text {th }}$ edition. This textbook is published by Pustaka Amanah Solo. This textbook is authored by Nurani Musta'in, AISM has five level books.

\subsection{Method}

The data were collected from the content of textbook that was evaluated based on the requirement of Government Regulation No. 32 of 2013 concerning National Education Standards article 43 that the assessment of textbooks uses 4 criteria, namely the feasibility of content, language, presentation and graphics. This standard is combined with other textbook valuation techniques, such as those of; Harmer[2]; and Cunningsworth[3]. There are stages of data collection. The researcher overviewed the general content of the textbook and familiarized herself with the data. The result of the data collection based on several factors and identifiers.

After the data had been analysis, the data was interpreting documentary data (textbook) refererd to content analysis. Firstly, the researcher got to know the data which was the textbook itself and tried to familiarize herself with the whole content of the book. Secondly, the researcher focused on the analysis is observed from the feasibility of textbooks which consist of the (1) feasibility of content, (2) presentation, (3) language, and (4) graphics.

The feasibility of the content of the textbook can be assessed from: the material is oriented towards activities that encourage understanding of the concept, the accuracy of the material is maintained, the up-to-date and the actualities of the sample material, the material encourages curiosity, and the material of the book does not contradict SARA, is not nuanced in pornography, accommodates diversity, and has a gender perspective.

The feasibility of presenting lesson textbooks can be assessed by encouraging student involvement for active learning, interrelationships between groups, between groups, and between concepts, integration/concepts between concepts, and material presented contextually.

The language feasibility of textbooks can be judged by the suitability of language with student development and the accuracy of the use of symbols, terms, and/or icons. The feasibility of graphic text of textbooks can be assessed from the layout of elements of aesthetic graphics, dynamic, interesting, illustrations that clarify understanding of book material, and typography used has a high level of legibility.

\section{Results and Discussion}

\subsection{Result}

Based on observations at Muhammadiyah Elementary School in Surakarta area, AISM textbook has becoming one of the supplementary book used by teachers to teach early reading, beside the main book published by national education agencies. AISM textbook has 3 volumes, consist of volume 1 which contains lessons reading vowel syllables "a", volume 2 containing reading lessons with vowels " $\mathrm{i}$ " and "u", and volume 3 containing reading lessons with vowels "e" and "o".

The analysis was guided by Government Paper No. 32 of 2013 about National Education Standards, article 43 states that the assessment of textbooks uses 4 criteria consst of the feasibility of content, language, presentation and graphics. This standard is combined with other textbook valuation techniques, such as Miekley, Harmer, Grant, Sheldon, and Cunningsworth. The results of the analysis of AISM textbook, shows in the table 1.1: 
Tabel 1 The feasibility AISM textbook

\begin{tabular}{|c|c|c|c|}
\hline No & Factors & Aspects & Result \\
\hline \multirow[t]{8}{*}{1.} & Content & $\begin{array}{l}\text { The material is activities- } \\
\text { oriented which encourage } \\
\text { understanding of concepts }\end{array}$ & $\begin{array}{l}\text { the material in this book has an easy- } \\
\text { to-understand concept }\end{array}$ \\
\hline & & Accuracy of material & $\begin{array}{l}\text { the material of this book has several } \\
\text { words that are less accurate in terms of } \\
\text { meaning }\end{array}$ \\
\hline & & $\begin{array}{l}\text { The material is encourages } \\
\text { curiosity }\end{array}$ & $\begin{array}{l}\text { material delivery techniques are very } \\
\text { monotonous and do not vary }\end{array}$ \\
\hline & & No rasist material & there is no word that causes racism \\
\hline & & No pornographic material & no pornographic material \\
\hline & & Accommodate diversity & $\begin{array}{l}\text { The material is packaged in a variety of } \\
\text { reading material for Islamic children, } \\
\text { so it does not accommodate diversity }\end{array}$ \\
\hline & & Gender insight & $\begin{array}{l}\text { the material presents examples that } \\
\text { clearly contain gender insights }\end{array}$ \\
\hline & & Employs concrete words & $\begin{array}{l}\text { there are words that are abstract and } \\
\text { difficult to understand by students }\end{array}$ \\
\hline \multirow[t]{4}{*}{2.} & $\begin{array}{l}\text { Organiz } \\
\text { ation }\end{array}$ & $\begin{array}{l}\text { Encourage the involvement of } \\
\text { active learning students }\end{array}$ & $\begin{array}{l}\text { this book is arranged in a bound book } \\
\text { and each volume uses the same method } \\
\text { of spelling syllables into words then } \\
\text { sentences. }\end{array}$ \\
\hline & & Linkages between volumes & $\begin{array}{l}\text { this book is arranged in volumes and } \\
\text { between volumes very closely related }\end{array}$ \\
\hline & & Linkage of concepts & $\begin{array}{l}\text { concepts compiled in each volume of } \\
\text { books related to other volumes, for } \\
\text { example volume } 1 \text { teaches reading } \\
\text { vowel syllables a, volume } 2 \text { reading } \\
\text { vowels u and i, etc. }\end{array}$ \\
\hline & & $\begin{array}{l}\text { Material is presented } \\
\text { contextually }\end{array}$ & $\begin{array}{l}\text { there is material that is not made that is } \\
\text { not in context, especially for early } \\
\text { grade students }\end{array}$ \\
\hline \multirow[t]{4}{*}{3.} & $\begin{array}{l}\text { Languag } \\
\text { e }\end{array}$ & $\begin{array}{l}\text { Language compatibility with } \\
\text { student development }\end{array}$ & $\begin{array}{l}\text { some words do not match the ability of } \\
\text { the early grade students to understand }\end{array}$ \\
\hline & & $\begin{array}{l}\text { The accuracy of the use of } \\
\text { punctuation or symbols }\end{array}$ & No punctuation and symbols \\
\hline & & $\begin{array}{l}\text { Accurate use of terms (word and } \\
\text { sentence) }\end{array}$ & $\begin{array}{l}\text { the use of words and sentences is in } \\
\text { accordance with grammar }\end{array}$ \\
\hline & & $\begin{array}{l}\text { Using language that is double } \\
\text { meaning }\end{array}$ & $\begin{array}{l}\text { there is no word that has a double } \\
\text { meaning }\end{array}$ \\
\hline \multirow[t]{5}{*}{4.} & Graphic & Accurate use of images & No picture \\
\hline & & Aesthetic graphical layout & the same typography on each sheet \\
\hline & & Dynamic graphic layout & No dynamic \\
\hline & & $\begin{array}{l}\text { Illustrations that clarify the } \\
\text { material }\end{array}$ & No illustration \\
\hline & & High readability of Typography & letters can be read \\
\hline
\end{tabular}




\subsection{Statement of results}

Based on the feasibility analysis, AISM textbook has content feasibility in terms of The material is activities-oriented which encourage understanding of concepts, No rasist material, No pornographic material, and gender-oriented. The components in the content feasibility analysis that are not fulfilled in AISM textbook are Accuracy of material, Timeliness of material, The material is encourages curiosity, and employs concrete words.

The feasibility analysis of the organization in AISM textbook has achieved its feasibility on the interrelationship between the principles and concepts. However, relating to activities that can encourage the involvement of active learning students and material presented contextually, based on this book's feasibility analysis this book has not fulfilled it.

The language used by AISM texbook is in accordance with aspects of conformity with student development, accuracy in the use of words, sentences, and ambigouity, apparently not fulfilling the eligibility requirements. AISM textbook does not introduce punctuation marks and symbols on students.

The use of graphics in AISM texbook has been quite good in the use of typography which is high in readability and layout that facilitates understanding of the material. The eligibility of graphics that needs to be improved in this book is the use of color, an aesthetic, dynamic, and attractive graphic layout, and illustrations that clarify the material.

\subsection{Discussion}

The Reading textbook entitled Anak Islam Suka Membaca (AISM) based on Government Regulation No. 32 of 2013 concerning National Education Standards article 43 that the assessment of textbooks uses 4 criteria, namely the feasibility of content, language, presentation and graphics. This standard is combined with other textbook valuation techniques, such as those of Miekley, Harmer, Grant, Sheldon, and Cunningsworth.

AISM is one of the textbooks used by teachers in Islamic elementary schools in Surakarta. As a learning support book, this book contains materials that teach students about reading the beginning. This textbook is prepared in accordance with the criteria expressed by Pannen and Purwanto[9]; Tarigan[6]; that textbooks are books that contain a description of the subject matter of a field, arranged systematically, and selected based on the objectives, development of students, and learning-oriented to be assimilated. AISM textbook is a tiered book, consisting of 5 volumes whose learning material is made from simple to complex. This study discusses 3 volumes of AISM books as follow volumes 1, 2, and 3 .

Each volume explains about packaged material to teach beginning reading. The method used by this textbook is the method of spelling. Purwantoro dan Alim[9]; Preliminary reading is the process of changing written symbols in the form of letters or words into meaningful sound systems or the like. This AISM book that teaches reading starts by introducing the sound of syllables into words, then becomes sentences.

In volume 1 it is contains vocal /a / syllable recognition which begins with placing vowels / a / in front of each alphabetical letter, such as "a", "ba", "ca" , "da", "fa", "ga", "ha",

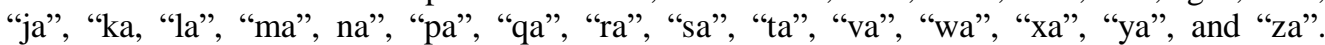
Volume 2 contains an introduction to vowels /i/ and /u/. With the same presentation technique as in volume 1 the author of this book makes the introduction technique begins by spelling out vocal "i" and "u" syllables beginning with alphabetical letters. Same with volume 2, volume 3 also begins with vocabulary recognition. The vowel letters introduced in this book are vowels "e" and "o". The presentation technique is the same as the previous book. 
In volume 1-3, although the purpose of the book introduces vocabulary with "a", "i:, "u", "e", "o" but the syllable presentation has a short distance so that when students spell it will form meaningful words, such as / ta / / xi /, / bu / / xu /, / a / / xu /, / du / / xu /, / ra / / fe /, / qe / / ju /, / qe // la / / pa /, / qe // la / / pa /, / qe // la / / in /, / qe / / bu / / li /, / xe / / la / / pa /, / xe / / ka / / li /, / qe / / na / / ri /, / xe / / na / / ri /, / xe / / na / / ri /, / fo / / bi /, / go / / ri /, and others. The application of this syllable presentation technique results in considerable errors, because the reader who is still at the stage of adding vocabulary is very likely to make the text in the book the real word.

The updated material in the book follows the times but is not in accordance with the development of language for grade 1 elementary school students which is seen in the selection of words that are too forced because of adjustments to the material to be conveyed. It can be seen in the example of the words "fa na", "ba ja", "ba qa", "la va", "ga za", and "ha ma". The selection of vocabulary that is unfamiliar to students results in students wanting to know the meaning of these words. When observed, some words also have a level of difficulty for students to understand, such as "fa na", "ba qa", "ja wa", "ma na ka la", "se ma ta", and "hu ra hu ra".

The material used to learn to read this beginning also has a combination of syllables that form the name of a region, for example, "to be lo di ma lu ku", and "wo no gi ri ko ta di ja wa". These can also be used to explore students' notification of an area. Language development in the early years, ways of thinking children are more concrete and focus on the context rather than more abstract traits that form the basis of the language found in simile or metaphor[12].

AISM textbook has no racist words or sentences. In addition, there are no pornographic material. The choice of syllables that form words or sentences in this book is more Islamic, such as" i la hi", "fu qa ra", "ba qa", and "fu qa ha". Therefore, AISM textbook does not show religious diversity. On the other hand, this book clearly distinguishes between gender, for example the use of "a bi" to call father and "u mi" for call mother. The examples of sentences are "pe ci a bi di ke pa la", "i bu be li me ri ca", "za ki ba wa pe la na ku da", "le la ki ja di je ja ka", "wa ni ta ja di je li ta".

The presentation of volumes 1-3 uses the same technique. The connection between volumes is very visible, namely in volume 1 starting with syllables with vowels "a"; volume 2 with vowel "i-u", and volume 3 vowel "e-o". The link between the concepts displayed in each book looks like the following pattern:

1. A syllable with vowel "a" starting from the first letter "a" to "z", for example "a ba ca da fa".

2. A syllable that all has a vocal but its placement is randomized, for example "a ba, ba, ba a, ca ca, ba ca, ca ba"

3. Forming syllables into repetitive or non-repetitive words while referring to syllables with a vowel, for example, "a ba a ba, baca baca, da ha ba ca, a da ga da". This pattern, have a word meaning, but some are not, for example, "a da ra ja, ka ya ra ya, a da la da, ada pa la"

4. Randomize all vocal syllables a. in this pattern it does not appear the meaning of the word that appears. This is very incompatible with the concept of preliminary reading which states that the purpose of teaching early reading is to provide skills to the issuer to convert a series of letters into meaningful sound circuits [9] [13].

5. In the last sheet written a collection of syllables which are a-form a sentence, for example

A da la ba la ba

Pa da ma ma ma

Ka la a da ha ma 
The choice of words which are the formations of syllables in the AISM book are many that are not contextual, for example: fa na, ba qa, ga za, ge ga na, ca ci ma ki, bi na, bu, bro, cu ti, fu ka ra , fu ka ha, fu a da, ga la, hu ma, hu ra hu ra, ju in, pu sa ra, pa ha la, qu lu bi, ca wu, ba yu, sa yu, and so on. The context built by this book for grade 1 elementary school students has high difficulties.

Punctuation and symbols are not found in this book. This is done because volume 1-3 is not in the framework of introducing sentences, even though the syllables written in the book actually have fulfilled the sentence structure, such as: yes, no, isn't it, bro? ba wa ja la.

The selection of terms that become material in this AISM book looks forced because of the approach to textbooks applied, ie each vowel must be preceded by a consonant, for example, the word / no ta / becomes the choice of words when the author will give an example of a starting syllable (words) / no / or the term / po of the person / chosen because it becomes an example of a syllable containing a vowel / o / beginning with the letter / $\mathrm{p} /$.

In terms of graphics can be observed from the start of the book display. AISM books have different color covers, but the reason is not explained. The difference in cover color is likely to make it easy to quickly detect volumes 1, 2 and 3.

The paper chosen to write material is white HVS. In volume 1, the material is written in black ink, volume 2 with orange ink, and volume 3 with blue ink. This also does not explain the intent and purpose.

The AISM book does not have drawing illustrations. All contents of the book are filled with letters. Likewise, the current updates of books to teach reading grade 1 elementary school, which is full of colors and images, is not owned by this book. From the typography aspect, the printed letters use the form of arial letters with a fairly legible size for grade 1 students of elementary school.

\section{Conclusion}

In sum, the researcher conclude that Anak Islam Suka Membaca is suitable for first graders of elementary school as either a supplementary textbook. Based on the finding, discussion, and conclusion of this textbook, researcher would like to present some suggestions for those who relates with textbook evaluation and educational field: the first suggestion is for teacher. Teacher is as facilitator, not instructor. As facilitators, teachers should facilitate their students by providing good materials. This materials also has weaknessess aspecially in terms of the availability of materials based on eligibility standards from BSNP and other education experts.

The second suggestion is for textbook publishers and evaluators. In publishing the textbook, textbook publishers should focused the criteria of good textbooks for elementary school. Therefore, the publishers and evaluators should be more careful in choosing content and ilustration for the textbook by considering the criteria from several experts.

The third suggestion is for the future researcher. The future researcher of textbook evaluation are expected to do some betterment toward the previous study of textbook evaluation. Several criteria of textbook from many different experts are provided and easily accesed. Therefore, the betterment might be on the careful adaptation from several criteria of treading textbook that should be filtered depending on the Indonesian context.

\section{References}

[1] L. Yuliyanti, "Gambaran perawatan ibu nifas di wilayah Kecamatan Miri Sragen," 
Universitas Muhammadiyah Surakarta, 2014.

[2] J. Harmer, No TitleaThe Practice of English Language Teaching. England: Pearson, 2001.

[3] A. Cunningsworth, Chosing Your Coursebook. Great Britain: The Bath Press, 1995.

[4] B. Tomlinson, Material Development in Language Teaching. Cambridge: Cambridge University Press, 1998.

[5] Wibowo, Manajemen Kinerja. Jakarta: PT. Raja Grafindo Persada, 2012.

[6] H. G. Tarigan, Reading as a Language Skill. Bandung: Angkasa Publiser, 2008.

[7] A. and Martono, "Study of Teachers' Perceptions of Early Reading Writing Learning in Early Class Elementary Schools," J. Pendidik., vol. 6 (1), pp. 13-24, 2006.

[8] Andayani, "Development of a Model for Teaching Reading Writing Teaching Materials with an Attractive Approach in Surakarta's Poor District Primary School," J. Kaji. Linguist. dan Sastra, vol. 22 (1), pp. 47-60, 2010.

[9] D. Purwanto, N. and Alim, Metodologi Pengajaran Bahasa Indonesia di Sekolah Dasar. Jakarta: Rosda Jayaputra, 1997.

[10] S. . Bogdan, R.C., and Biklen, Qualitative Research. Needham Height, MA: Allyn and Bacon, 2001.

[11] B. Anderson, Imagined Communities (Komunitas-Komunitas Terbayang). Yogyakarta: INSIST dan Pustaka Pelajar, 2008.

[12] B. Otto, Language Development in Early Childhood: Third Edition. Boston: Pearson Merril, 2015.

[13] S. Y. Amelia, D. J. and Saputra, "Book Feasibility Analysis Class IV Students Theme 2013 Living Behavior Curriculum," J. Pendidik., vol. 6 (1), pp. 98-109, 2017. 